\title{
Pengaruh Rasio Likuiditas, Rasio Biaya, Kecukupan Modal, dan Risiko Kredit sebagai Moderasi terhadap Profitabilitas Bank
}

\author{
Camilla Casimira Kurniawan ${ }^{1}$ \\ Fakultas Ekonomi \\ Universitas Katolik Parahyangan, \\ Indonesia
}

\author{
Judith Felicia Pattiwael Irawan² \\ Fakultas Ekonomi \\ Universitas Katolik Parahyangan, \\ Indonesia
}

\begin{abstract}
Surel : judith@unpar.ac.id
\section{ABSTRAK}

Pandemi tahun 2020 mempengaruhi sektor ekonomi termasuk perbankan, terutama kategori BUKU 1. Penelitian ini bertujuan mengidentifikasi faktor-faktor internal yang mempengaruhi profitabilitas bank pada kondisi normal tahun 2019 dibandingkan kondisi dimana pertumbuhan ekonomi mengalami kontraksi akibat pandemi tahun 2020. Studi ini didasari teori Asset-Liability Management (ALM) dan menggunakan metode regresi linier berganda dengan ROA sebagai alat ukur profitabilitas, LDR, BOPO, dan CAR sebagai variabel independen, serta NPL sebagai quasi moderator. Hasil penelitian memberikan temuan bahwa untuk menjaga profitabilitasnya, bank perlu memperhatikan efisiensi biaya yang diperkuat oleh risiko kredit macet. Sedangkan dalam kondisi tidak stabil, ada penambahan faktor risiko likuiditas yang juga harus mendapat perhatian. Maka, hasil penelitian ini sejalan dengan pendekatan liability management.
\end{abstract}

Kata Kunci: Profitabilitas Bank; Kondisi Normal; Kontraksi Pertumbuhan Ekonomi.

\section{Effect of Liquidity Ratio, Cost Ratio, Capital Adequacy, and Credit Risk as Moderation on Bank Profitability}$$
\text { ABSTRACT }
$$

The 2020 pandemic affected the economic sector, including banking sector, especially banks in the BUKU 1 category. This study aims to identify internal factors that affect bank profitability between normal conditions in 2019 and conditions when economic growth experienced a contraction due to the pandemic in 2020. This study is based on the theory of Asset-Liability Management (ALM) and uses multiple linear regression method with ROA as a measure of profitability, LDR, BOPO, and CAR as independent variables, and NPL as quasi moderator. The results of this study provide findings that to maintain profitability, banks need to pay attention to cost efficiency which is reinforced by the risk of bad loans. Meanwhile, in unstable conditions, there are additional liquidity risk factor that must also receive attention. Thus, the results of this study are in line with the liability management approach.
}

Keywords: Bank profitability; Normal Condition, Contraction of Economic Growth.

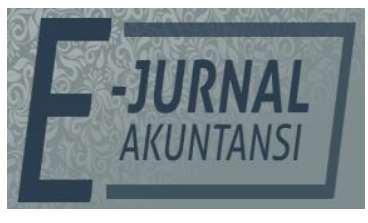

e-ISSN 2302-8556

Vol. 31 No. 12

Denpasar, Desember 2021

Hal. 3178-3194

DOI:

10.24843/EJA.2021.v31.i12.p11

PENGUTIPAN:

Kurniawan, C. C. \& Irawan, J. F. P. (2021). Pengaruh Rasio

Likuiditas, Rasio Biaya,

Kecukupan Modal, dan Risiko Kredit sebagai Moderasi terhadap

Profitabilitas Bank. E-Jurnal Akuntansi, 31(12), 3178-3194

RIWAYAT ARTIKEL:

Artikel Masuk:

7 Agustus 2021

Artikel Diterima:

13 Desember 2021

Artikel dapat diakses : https://ojs.unud.ac.id/index.php/Akuntansi/index 


\section{PENDAHULUAN}

Masyarakat dunia menghadapi pandemi pada 2020, mengikuti pernyataan resmi dari WHO yang menetapkan wabah virus corona sebagai pandemi global pada 11 Maret 2020. Pandemi virus corona atau Covid-19 yang melanda dunia, ternyata tidak hanya mempengaruhi sektor kesehatan tetapi juga mempengaruhi sektor keuangan. Salah satu penggerak utama PDB Indonesia adalah perbankan, dimana perbankan berperan sebagai intermediary dari kegiatan konsumsi, investasi, dan kegiatan ekspor impor (Winarto, 2020). Menurut pernyataan Republika.co.id (2021), pandemi global menyebabkan pertumbuhan laba bersih BUKU 1 dan BUKU 4 mengalami kontraksi paling dalam masing-masing minus 56,5 persen dan minus 37,14 persen. Dengan demikian, ketidakstabilan perekonomian akibat pandemi global berpengaruh paling besar terhadap kontraksi pertumbuhan laba bersih BUKU 1 yang memiliki permodalan paling rendah dibandingkan kategori lainnya. Berikut adalah pertumbuhan laba yang diwakili oleh return on asset (ROA) pada industri perbankan dan BUKU 1 selama tahun 2019 - 2020 berdasarkan Laporan Profil Industri Perbankan.

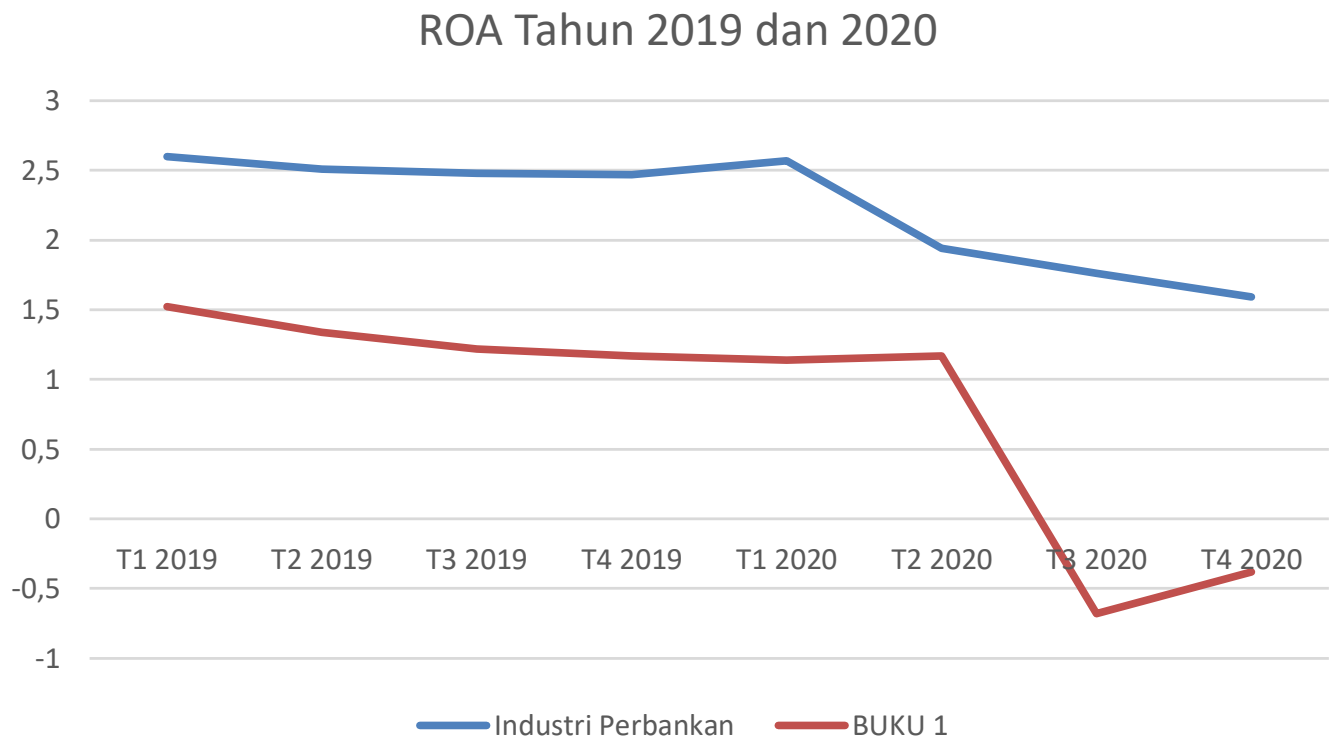

Gambar 1. ROA Perbankan Indonesia Tahun 2019 - 2020

\section{Sumber: Data Penelitian, 2021}

Pada Gambar 1 ROA industri perbankan dan Buku 1 cukup stabil selama tahun 2019, namun menurun pada tahun 2020. ROA industri perbankan mulai menurun pada triwulan kedua tahun 2020, sedangkan ROA BUKU 1 menurun drastis pada triwulan ketiga 2020. Fokus penelitian ini adalah faktor-faktor internal yang mempengaruhi penurunan ROA saat pandemi di tahun 2020 yang belum pernah terjadi sebelumnya, dibandingkan kondisi normal di tahun 2019.

Sehubungan dengan proses pengambilan keputusan atas aset dan liabilitas pada lembaga keuangan, Rose \& Hudgins (2013) menjelaskan adanya tiga pendekatan yaitu asset management, liability management, dan funds management. Menurut pendekatan asset management, pengambilan keputusan utama lembaga keuangan adalah terhadap asetnya. Sedangkan pendekatan liability management bertujuan mengontrol sumber dana melalui harga. Tetapi, pendekatan funds 
management memastikan pengambilan keputusan terkait aset maupun liabilitas tidak saling berlawanan.

Salah satu indikator kualitas kinerja keuangan adalah profitabilitas, dengan alat ukurnya return on assets (ROA). Menurut Rose \& Hudgins (2013), "ROA is primarily an indicator of managerial efficiency; it indicates how capable management has been in converting assets into net earnings." Terdapat sejumlah penelitian yang mengukur kinerja profitabilitas bank, seperti Ercegovac et al., 2020; Hunjra et al., 2020; Nisar et al., 2017; Shahid1 et al., 2019; Sofie et al., 2020; Topak \& Talu, 2017. Beberapa studi memfokuskan penelitiannya pada satu negara, seperti Turki (Topak \& Talu, 2017), Pakistan (Shahid1 et al., 2019), Serbia (Knezevic \& Dobromirov, 2016), Kroasia (Kramaric et al., 2017), dan Yordania (Saleh \& Abu Afifa, 2020). Sedangkan studi lain membandingkan sekelompok negara, seperti negara-negara Uni Eropa (Korytowski, 2018), negara-negara yang termasuk dalam Masyarakat Ekonomi Negara-Negara Afrika Barat (Economic Community of West African States/ECOWAS) (Adelopo et al., 2018), negara-negara V4 atau aliansi empat negara di Eropa Tengah (Gyulai \& Szucs, 2017), dan 47 negara di Asia (SaifAlyousfi, 2020). Ada penelitian terhadap beberapa periode waktu, seperti sebelum, selama, dan setelah krisis ekonomi (Adelopo et al., 2018; Nisar et al., 2017), atau selama kondisi normal dan krisis ekonomi (Kramaric et al., 2017). Studi ini juga mengukur profitabilitas bank. Namun, pengukuran dilakukan pada dua periode waktu yang masing-masing dalam kondisi berbeda. Tahun 2019 merupakan kondisi normal, dibandingkan tahun 2020 saat pertumbuhan ekonomi mengalami kontraksi akibat pandemi covid-19 yang belum pernah terjadi sebelumnya.

Penelitian terhadap faktor-faktor yang mempengaruhi profitabilitas bank di Indonesia sudah dilakukan, seperti pada bank syariah (Ardana, 2018; Nuha \& Mulazid, 2018; Sudarsono, 2017) dan Bank Perkreditan Rakyat (Afriyeni \& Fernos, 2018; Sofyan, 2019). Prasanto et al. (2020) mengukur pengaruh jangka pendek dan jangka panjang faktor-faktor internal terhadap profitabilitas bank BUMN. Sofie $e t$ al. (2020) meneliti faktor-faktor yang mempengaruhi profitabilitas bank dengan ukuran bank sebagai variabel moderator. Sedangkan Jumono et al. (2018) meneliti faktor-faktor internal berupa karakteristik bank dan faktor-faktor eksternal berupa struktur pasar dan variabel makroekonomi terhadap profitabilitas bank di Indonesia. Penelitian yang menggunakan variabel independen LDR dan BOPO, dengan NPL sebagai quasi moderator telah dilakukan oleh Wicaksana \& Ramantha (2019). Studi ini juga melibatkan variabel NPL sebagai quasi moderator. Perbedaannya dengan penelitian sebelumnya, variabel NPL pada penelitian ini difokuskan untuk menyoroti situasi perekonomian yang tidak stabil akibat pandemi pada tahun 2020. Hasil penelitian Park \& Shin (2021) terhadap sistem perbankan global menunjukkan bahwa seiring dengan meningkatnya kerugian korporasi karena perlambatan ekonomi akibat Covid-19, risiko gagal bayar dapat terwujud dan memicu peningkatan NPL.

Penelitian ini bertujuan untuk mengukur faktor-faktor internal yang mempengaruhi profitabilitas bank kategori BUKU 1. Dalam hal ini, faktor-faktor internal adalah risiko likuiditas dengan indikator Loan to Deposit (LDR), efisiensi biaya dengan indikator Biaya Operasional terhadap Pendapatan Operasional 
(BOPO), kecukupan modal dengan indikator Capital Adequacy Ratio (CAR), dan risiko kredit dengan indikator Non-Performing Loan (NPL).

Risiko likuiditas adalah risiko yang muncul ketika bank tidak dapat memenuhi kewajibannya. Menurut Hunjra et al. (2020), risiko ini dapat berpengaruh negatif terhadap kinerja bank. Oleh karena itu, prioritas manajemen bank adalah memastikan kecukupan dana tersedia dengan biaya yang wajar untuk memenuhi kebutuhan deposan dan masa depan peminjam. Salah satu alat ukurnya adalah rasio Loan to Deposit (LDR). Semakin banyak pinjaman yang diberikan, maka semakin banyak juga pendapatan bunga yang diperoleh bank. Namun LDR yang terlalu tinggi menyebabkan bank sulit memenuhi kewajiban pembayarannya sehingga berdampak negatif bagi laba dan reputasi bank. Hasil penelitian Hunjra et al. (2020), Sofie et al. (2020), dan Parenrengi \& Hendratni (2018) menunjukkan hubungan yang negatif dan signifikan antara LDR terhadap profitabilitas bank. Hal tersebut berbeda dengan hasil penelitian Pinasti \& Mustikawati (2018) dimana LDR tidak berpengaruh signifikan terhadap profitabilitas bank.

$\mathrm{H}_{1}$ : Risiko Likuiditas berpengaruh signifikan negatif terhadap profitabilitas bank.

Salah satu indikator untuk mengukur efisiensi biaya adalah rasio Biaya Operasional terhadap Pendapatan Operasional (BOPO), dimana semakin besar rasio $\mathrm{BOPO}$ maka semakin besar porsi pendapatan operasional yang dikonsumsi oleh biaya operasional sehingga profit akan semakin berkurang. Menurut pernyataan Wicaksana \& Ramantha (2019): “BOPO merupakan rasio perbandingan antara biaya operasional dengan pendapatan operasional. Semakin besar BOPO, maka akan semakin kecil atau menurun kinerja keuangan perbankan." Hasil penelitian Wicaksana \& Ramantha (2019) menunjukkan bahwa rasio BOPO berpengaruh negatif dan signifikan terhadap profitabilitas bank. Temuan ini sesuai dengan hasil penelitian Sofie et al. (2020).

$\mathrm{H}_{2}$ : Efisiensi Biaya berpengaruh signifikan negatif terhadap profitabilitas bank.

Kecukupan modal yang diukur dengan Capital Adequacy Ratio (CAR) atau rasio kecukupan modal adalah indikator dari kekuatan modal. Bank dengan permodalan yang kuat akan lebih mampu menghadapi risiko perbankan dan akan menghasilkan profit yang lebih baik. Menurut Salike \& Ao (2018) yang melakukan penelitian pada bank di Asia, semakin tinggi rasio ekuitas terhadap aset maka semakin rendah risiko kebangkrutan yang mungkin dihadapi bank. Pernyataan ini didukung oleh penelitian Nisar et al. (2017) pada bank di Pakistan, penelitian Saleh \& Abu Afifa (2020) pada bank di Yordania, dan penelitian (Sugiarto \& Lestari, 2017) pada bank yang terdaftar di Bursa Efek Indonesia periode 2006 2015. Namun, berlawanan dengan hasil penelitian Topak \& Talu (2017) serta Shahid1 et al. (2019) yang menunjukkan adanya hubungan negatif dan signifikan terhadap ROA.

$\mathrm{H}_{3}$ : Kecukupan Modal berpengaruh signifikan positif terhadap profitabilitas bank.

Salah satu indikator untuk mengukur risiko kredit adalah rasio NonPerforming Loans to Total Loans (NPL). Menurut (Rose \& Hudgins, 2013), kemungkinan nilai dari sebagian aset milik lembaga keuangan menurun atau mungkin menjadi tidak berharga, dikenal sebagai risiko kredit. Maka, NPL berdampak negatif terhadap profitabilitas bank. Semakin tinggi rasio NPL atau kredit bermasalah maka akan semakin mengurangi pendapatan bunga bank. 
Hasil penelitian Hunjra et al. (2020) menunjukkan bahwa rasio NPL berpengaruh secara negatif dan signifikan terhadap profitabilitas bank. Hasil penelitian ini sesuai dengan hasil penelitian Nisar et al. (2017).

$\mathrm{H}_{4}$ : Risiko Kredit berpengaruh signifikan negatif terhadap profitabilitas bank.

Kondisi perekonomian yang tidak stabil tercermin oleh rasio NPL sebagai indikator risiko kredit yang mempengaruhi hubungan antara risiko likuiditas terhadap profitabilitas bank. Hasil penelitian sebelumnya menunjukkan bahwa Rasio LDR berpengaruh negatif terhadap profitabilitas (Hunjra et al., 2020; Parenrengi \& Hendratni, 2018; Sofie et al., 2020), begitupun dengan rasio NPL (Hunjra et al., 2020), (Nisar et al., 2017). Hal ini berlawanan dengan penelitian Wicaksana \& Ramantha (2019) yang menunjukkan bahwa rasio NPL memperlemah pengaruh rasio LDR terhadap profitabilitas bank.

$\mathrm{H}_{5}$ : Risiko Kredit memperkuat pengaruh Risiko Likuiditas terhadap profitabilitas bank.

Selain risiko likuiditas, risiko kredit juga mempengaruhi hubungan antara efisiensi biaya terhadap profitabilitas bank. Rasio BOPO berpengaruh negatif dan signifikan terhadap profitabilitas bank (Sofie et al., 2020; Wicaksana \& Ramantha, 2019), begitupun dengan rasio NPL (Hunjra et al., 2020), (Nisar et al., 2017). Sedangkan berdasarkan hasil penelitian Wicaksana \& Ramantha (2019), rasio NPL memperkuat pengaruh rasio BOPO terhadap profitabilitas bank. Dengan demikian, dapat disusun hipotesa keenam sebagai berikut.

$\mathrm{H}_{6}$ : Risiko Kredit memperkuat pengaruh Efisiensi Biaya terhadap profitabilitas bank.

Dalam kondisi perekonomian yang tidak stabil, risiko kredit juga mempengaruhi hubungan antara kecukupan modal terhadap profitabilitas bank. Hasil penelitian terhadap rasio NPL menunjukkan bahwa rasio NPL berpengaruh signifikan negatif terhadap profitabilitas bank (Hunjra et al., 2020; Nisar et al., 2017), sedangkan hasil penelitian terhadap rasio CAR menunjukkan bahwa rasio CAR berpengaruh signifikan positif terhadap profitabilitas (Nisar et al., 2017), (Saleh \& Abu Afifa, 2020), (Salike \& Ao, 2018), (Sugiarto \& Lestari, 2017), maka dapat disusun hipotesa ketujuh sebagai berikut.

$\mathrm{H}_{7}$ : Risiko Kredit memperlemah pengaruh Kecukupan Modal terhadap profitabilitas bank.

Penelitian ini sejalan dengan usulan penelitian Wicaksana \& Ramantha (2019) yang menyarankan penggunaan variabel bebas lain yang dapat berpengaruh terhadap profitabilitas. Dengan demikian, penelitian ini menambahkan Kecukupan Modal dengan indikator CAR sebagai variabel bebas. Dengan mengambil periode waktu mulai dari triwulan 2 sampai dengan triwulan 4 tahun 2019 dimana kondisi perekonomian normal yang kemudian dibandingkan dengan periode waktu yang bersesuaian pada triwulan 2 sampai dengan triwulan 4 tahun 2020 dimana kondisi perekonomian tidak stabil, penelitian ini bertujuan mengukur dan mengidentifikasi perbedaan faktor-faktor internal yang mempengaruhi profitabilitas bank pada dua periode waktu yang berbeda. 


\section{METODE PENELITIAN}

Pada penelitian ini, populasi yang diteliti adalah seluruh bank umum konvensional di Indonesia yang termasuk dalam kategori Bank Umum berdasarkan Kegiatan Usaha (BUKU) 1. Sampai dengan 31 Desember 2020, terdapat 13 bank umum konvensional yang termasuk kategori BUKU 1 (Nurul, 2020). Penelitian ini menggunakan data sekunder yang diperoleh dari laporan tahunan bank umum konvensional di Indonesia yang termasuk dalam kategori BUKU 1 selama periode triwulan 2 sampai dengan triwulan 4 tahun 2019 dan tahun 2020.

Variabel dependen dalam penelitian ini adalah return on asset (ROA) untuk mengukur profitabilitas bank. Perhitungan ROA sebagai berikut.

Return On Asset $(\mathrm{ROA})=($ Net Income $) /($ Total Asset $)$.

Variabel independen merepresentasikan faktor-faktor yang mempengaruhi profitabilitas bank. Penelitian ini melibatkan empat variabel internal bank yaitu Risiko Likuiditas, Efisiensi Biaya, Kecukupan Modal, dan Risiko Kredit. Indikator yang digunakan untuk mengukur risiko likuiditas adalah Loan to Deposit Ratio (LDR). Perhitungan LDR sebagai berikut:

LDR $=($ Total Loan $) /($ Total Deposits from Customers $)$

Indikator yang digunakan untuk mengukur efisiensi biaya adalah biaya operasional terhadap pendapatan operasional (BOPO). Perhitungan rasio BOPO sebagai berikut:

$\mathrm{BOPO}=($ Biaya Operasional $) /($ Pendapatan Operasional $)$.

Indikator yang digunakan untuk mengukur kecukupan modal adalah Capital Adequacy Ratio (CAR). Perhitungan CAR sebagai berikut:

CAR $=($ Total Ekuitas $) /($ Total Aset Tertimbang Menurut Risiko $)$

Indikator yang digunakan untuk mengukur risiko kredit adalah Non-performing Loans to Total Loans (NPL). Perhitungan rasio NPL sebagai berikut:

$\mathrm{NPL}=($ Non-Performing loans $) /($ Total Loans $)$

Metode analisis yang digunakan pada penelitian ini adalah metode deskriptif dan metode regresi linier berganda. Sebelum melakukan analisis regresi linier berganda, perlu dilakukan uji asumsi klasik, yaitu uji normalitas, uji heteroskedastisitas, dan uji multikolinieritas. Pengujian persamaan regresi penelitian ini menggunakan SPSS Statistics 22. Model persamaan regresi penelitian ini adalah sebagai berikut:

ROAit $=a 0+\beta 1$ LDRit $+\beta 2$ BOPOit $+\beta 3$ CARit $+\beta 4 N P L i t+\beta 5\left(L_{D R} * N P L\right)+\beta 6(B O P O * N$

$\mathrm{PL})+\beta 7\left(\mathrm{CAR}{ }^{*} \mathrm{NPL}\right)+\varepsilon i t$

Keterangan:

$\mathrm{i} \quad=$ Bank

$\mathrm{t} \quad=$ Periode Waktu Penelitian

$\mathrm{a} \quad=$ Konstanta

$\beta=$ Koefisien Regresi

$\varepsilon \quad=$ Error

\section{HASIL DAN PEMBAHASAN}

Hasil analisis statistik deskriptif menunjukkan gambaran (deskripsi) perihal perilaku data, seperti nilai terendah, nilai tertinggi, sebaran, rata-rata, deviasi standar, dan varians data. 
Tabel 1. Hasil Analisis Statistik Deskriptif Penelitian Data 2019

\begin{tabular}{lllc}
\hline & N & Mean & Std. Deviation \\
\hline ROA & 39 & 0,003 & 0,033 \\
LDR & 39 & 0,862 & 0,174 \\
BOPO & 39 & 0,991 & 0,343 \\
CAR & 39 & 0,252 & 0,233 \\
NPL & 39 & 0,039 & 0,021 \\
\hline
\end{tabular}

Sumber: Data Penelitian, 2021

Pada Tabel 1 dilihat jumlah populasi (N) penelitian ini adalah 39. Mean yang dimiliki ROA sebesar 0,00274, artinya rata-rata ROA bank kategori BUKU 1 selama periode triwulan 2 sampai dengan 4 tahun 2019 adalah 0,00274. Sedangkan standar deviasi atau penyimpangan nilai terhadap rata-rata ROA adalah 0,033203.

Untuk menguji apakah nilai residu dari regresi mempunyai distribusi normal, maka dilakukan Uji Normalitas, yang ditampilkan pada normal probability plot.

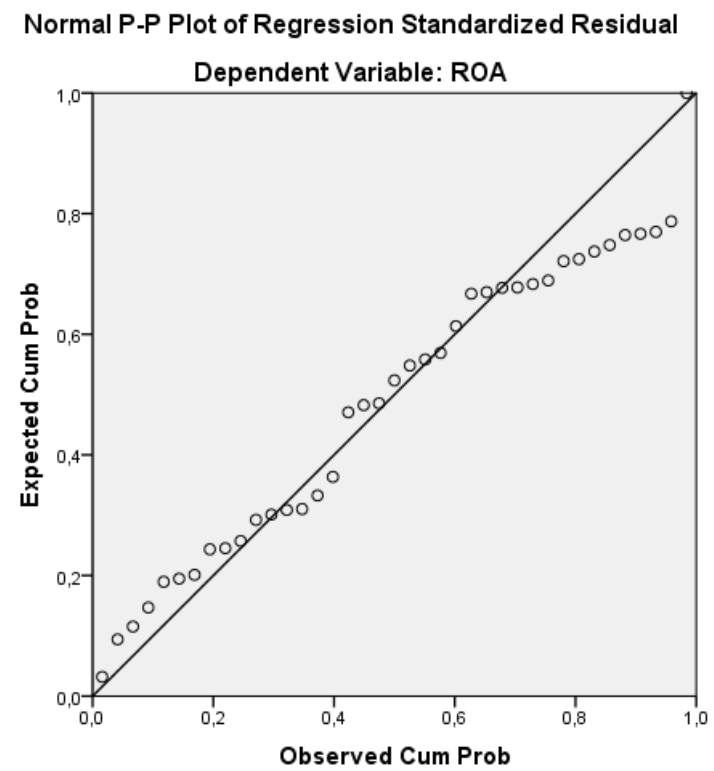

Gambar 2. Hasil Uji Normalitas Data 2019

Sumber: Data Penelitian, 2021

Pada Gambar 2, dilihat bahwa data berdistribusi normal karena sebaran data di sekitar garis diagonal, begitupun arahnya mengikuti garis tersebut. Selanjutnya dilakukan Uji Heteroskedastisitas untuk mengetahui apakah varians residual dari satu pengamatan sama atau tidak sama dengan varians residual dari pengamatan yang lain.

Pada Gambar 3, dapat dilihat hasil Uji Heteroskedastisitas berupa scatterplot, dimana penyebaran titik-titik tidak membentuk suatu pola yang teratur, artinya tidak terdapat masalah heteroskedastisitas. Untuk menguji apakah pada model regresi ditemukan adanya korelasi antar variabel independen, maka dilakukan Uji Multikolinieritas. 


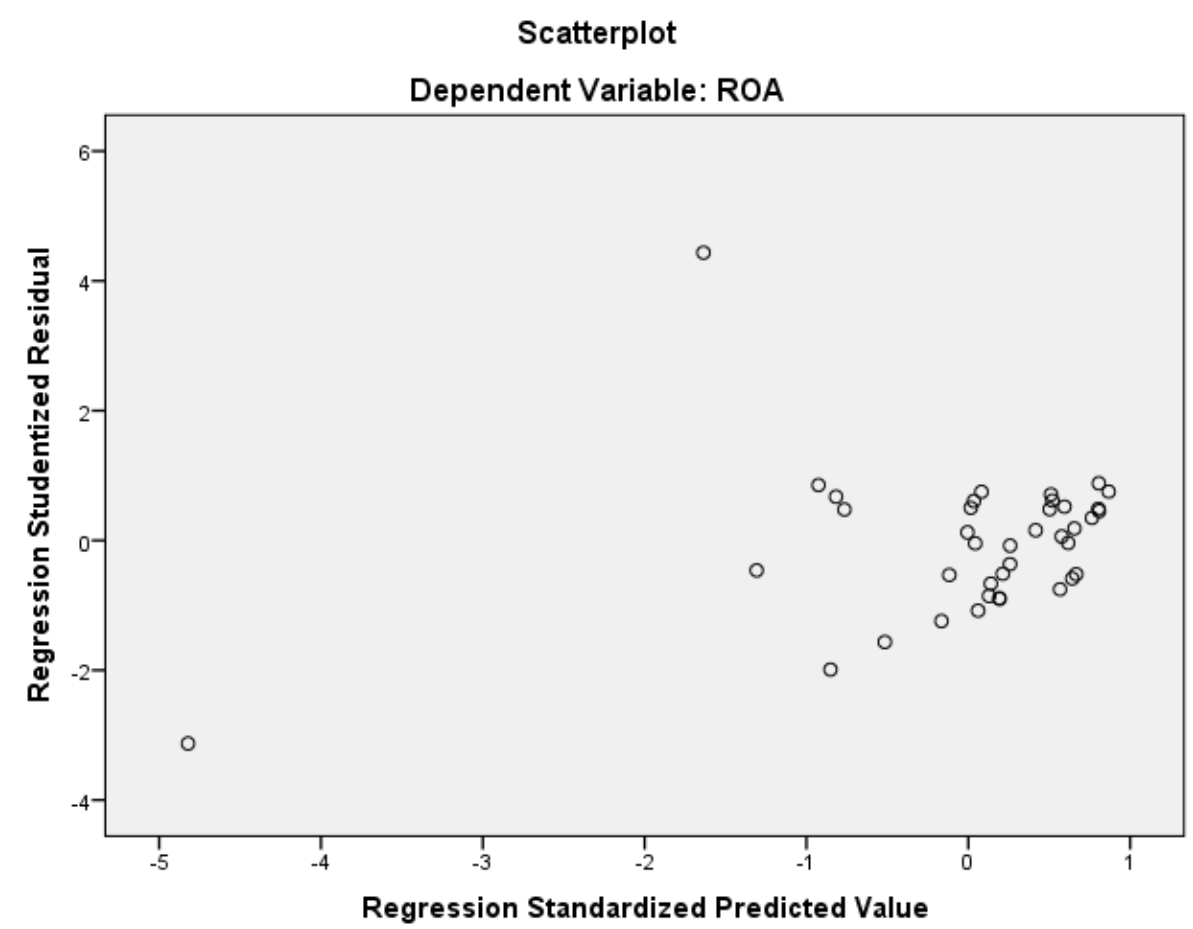

Gambar 3. Hasil Uji Heteroskedastisitas Data 2019

Sumber: Data Penelitian, 2021

Tabel 2. Hasil Uji Multikolinieritas Data 2019

\begin{tabular}{lcc}
\hline Model & \multicolumn{2}{c}{ Collinearity Statistics } \\
\cline { 2 - 3 } & Tolerance & VIF \\
\hline LDR & 0,682 & 1,467 \\
BOPO & 0,337 & 2,969 \\
CAR & 0,446 & 2,244 \\
NPL & 0,547 & 1,827 \\
\hline
\end{tabular}

Sumber: Data Penelitian, 2021

Pada Tabel 2, dapat dilihat hasil Uji Multikolinieritas, dimana terdapat dua variabel yaitu CAR dan BOPO yang tidak mempunyai nilai collinearity tolerance mendekati angka 1 dan tidak mempunyai nilai VIF di sekitar angka 1. Artinya terdapat korelasi antar-variabel CAR dan BOPO. Maka peneliti melakukan uji ulang dengan mengeluarkan variabel CAR dari model regresi. Uji Normalitas dilakukan kembali untuk menguji apakah nilai residu dari regresi yang baru mempunyai distribusi normal.

Pada Gambar 4 dapat dilihat hasil Uji Normalitas yaitu data berdistribusi normal. Selanjutnya, dilakukan kembali Uji Heteroskedastisitas terhadap model regresi baru. Pada Gambar 5 dapat dilihat hasil Uji Heteroskedastisitas yaitu tidak terdapat masalah heteroskedastisitas karena penyebaran titik-titik yang tidak teratur dan tidak membentuk pola tertentu. Untuk menguji apakah pada model regresi ditemukan adanya korelasi antar-variabel independent LDR, BOPO, dan NPL, maka dilakukan Uji Multikolinieritas. 


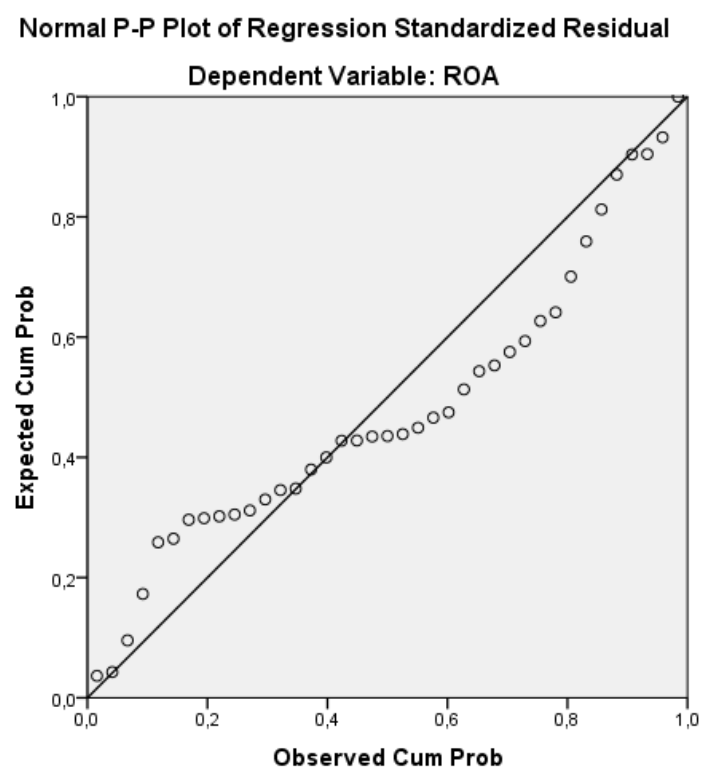

Gambar 4. Hasil Uji Normalitas Data 2019 (2)

Sumber: Data Penelitian, 2021

Scatterplot

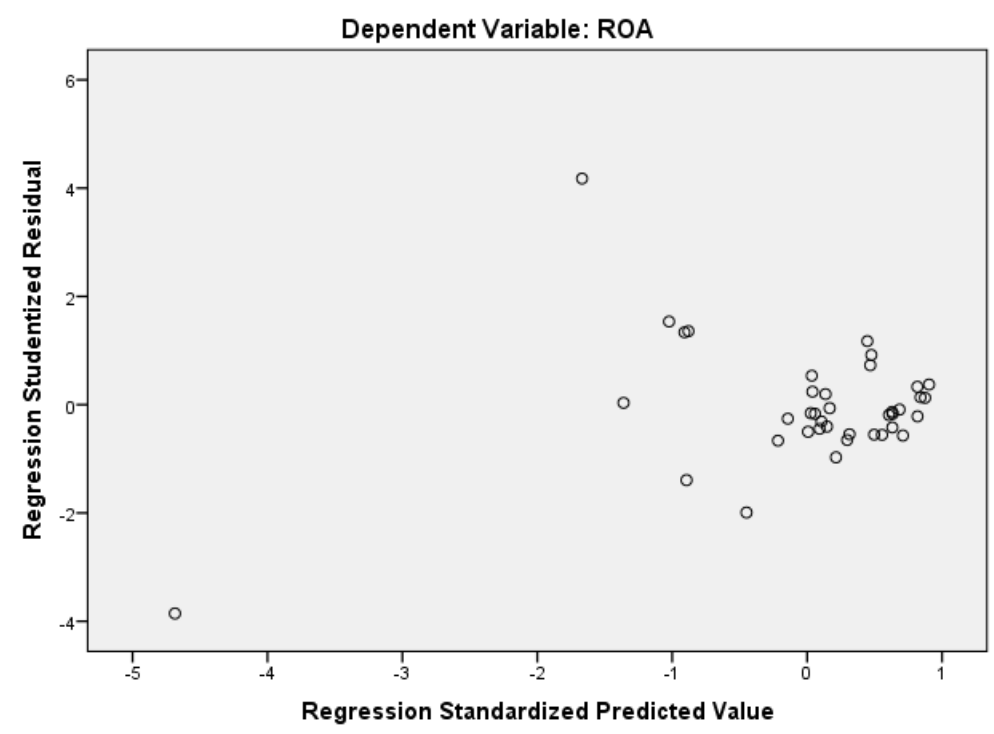

Gambar 5. Hasil Uji Heteroskedastisitas Data 2019 (2)

Sumber: Data Penelitian, 2021

Tabel 3. Hasil Uji Multikolinieritas Data 2019 (2)

\begin{tabular}{lcc}
\hline Model & \multicolumn{2}{c}{ Collinearity Statistics } \\
\cline { 2 - 3 } & Tolerance & VIF \\
\hline LDR & 0,807 & 1,239 \\
BOPO & 0,703 & 1,422 \\
NPL & 0,858 & 1,166 \\
\hline
\end{tabular}

Sumber: Data Penelitian, 2021

Pada Tabel 3 dapat dilihat hasil Uji Multikolinieritas, dimana ketiga variabel independen memiliki nilai collinearity tolerance mendekati angka 1 dan mempunyai nilai VIF di sekitar angka 1. Artinya tidak terdapat korelasi antarvariabel independen. Untuk menguji kesesuaian data maka dilakukan Uji 
Kesesuaian Model (goodness of fit) - F test yang hasilnya dapat dilihat pada tabel ANOVA.

Tabel 4. Hasil Uji Kesesuaian Model (F-test) Data 2019

\begin{tabular}{llccccc}
\hline Model & & $\begin{array}{c}\text { Sum of } \\
\text { Squares }\end{array}$ & $d f$ & $\begin{array}{c}\text { Mean } \\
\text { Square }\end{array}$ & $F$ & Sig. \\
\hline 1 & Regression & 0,041 & 3 & 0,014 & 850,852 & $0,000^{\mathrm{b}}$ \\
& Residual & 0,001 & 35 & 0,000 & & \\
& Total & 0,042 & 38 & & & \\
\hline
\end{tabular}

Sumber: Data Penelitian, 2021

Pada Tabel 4 dapat dilihat bahwa $p$-value sebesar $0,000^{\mathrm{b}}$ yang lebih kecil dari $\mathrm{a}=$ 0,05 . Maka dapat disimpulkan bahwa model regresi yang digunakan layak dan variabel-variabel independen dapat menjelaskan fenomena profitabilitas. Hasil pengujian model regresi dengan variabel independen LDR, BOPO, dan NPL, dimana NPL merupakan variabel moderasi, sebagai berikut.

Tabel 5. Hasil Analisis Regresi Data 2019

\begin{tabular}{|c|c|c|c|c|c|c|}
\hline \multirow[t]{2}{*}{ Moc } & & \multicolumn{2}{|c|}{$\begin{array}{l}\text { Unstandardized } \\
\text { Coefficients }\end{array}$} & \multirow{2}{*}{$\begin{array}{c}\text { Standardized } \\
\text { Coefficients }\end{array}$} & \multirow[t]{2}{*}{$\mathrm{t}$} & \multirow[t]{2}{*}{ Sig. } \\
\hline & & $\mathrm{B}$ & Std. Error & & & \\
\hline \multirow[t]{6}{*}{1} & (Constant) & 0,101 & 0,007 & & 14,688 & 0,000 \\
\hline & LDR & 0,008 & 0,006 & 0,040 & 1,320 & 0,196 \\
\hline & BOPO & $-0,105$ & 0,003 & $-1,090$ & $-34,155$ & 0,000 \\
\hline & NPL & 0,006 & 0,223 & 0,004 & 0,028 & 0,978 \\
\hline & LDR.NPL & $-0,362$ & 0,189 & $-0,199$ & $-1,912$ & 0,065 \\
\hline & BOPO.NPL & 0,287 & 0,090 & 0,263 & 3,184 & 0,003 \\
\hline
\end{tabular}

Sumber: Data Penelitian, 2021

Tabel 5 memperlihatkan bahwa variabel LDR, NPL, dan variabel interaksi LDR.NPL memiliki $p$-value lebih besar dari $a=0,05$, yang berarti ketiga variabel tersebut tidak memiliki pengaruh yang signifikan terhadap profitabilitas. Oleh karena itu, peneliti kembali menguji model regresi dengan menggunakan variabel yang memiliki $p$-value lebih kecil dari $\alpha=0,05$, yaitu BOPO dan variabel interaksi $\mathrm{X} 2 . \mathrm{Z}$.

Tabel 6. Hasil Analisis Regresi Data 2019 (2)

\begin{tabular}{|c|c|c|c|c|c|c|}
\hline \multirow[t]{2}{*}{ Model } & & \multicolumn{2}{|c|}{$\begin{array}{l}\text { Unstandardized } \\
\text { Coefficients }\end{array}$} & \multirow{2}{*}{$\begin{array}{c}\begin{array}{c}\text { Standardized } \\
\text { Coefficients }\end{array} \\
\text { Beta }\end{array}$} & \multirow[t]{2}{*}{$\mathrm{t}$} & \multirow[t]{2}{*}{ Sig. } \\
\hline & & B & Std. Error & & & \\
\hline \multirow[t]{3}{*}{1} & (Constant) & 0,099 & 0,002 & & 51,352 & 0,000 \\
\hline & ВOPO & $-0,099$ & 0,002 & $-1,024$ & $-43,042$ & 0,000 \\
\hline & BOPO.NPL & 0,054 & 0,026 & 0,050 & 2,094 & 0,043 \\
\hline
\end{tabular}

Sumber: Data Penelitian, 2021

Berdasarkan Tabel 6, maka hasil akhir modelnya sebagai berikut.

$$
\mathrm{ROA}=0,099-0,099 \mathrm{BOPO}+0,054 \mathrm{BOPO} . \mathrm{NPL}
$$

Artinya, pada $\mathrm{H} 2$, yaitu Efisiensi Biaya (BOPO) berpengaruh signifikan negatif terhadap profitabilitas bank. Begitu juga dengan H6, yaitu Risiko Kredit (NPL), sebagai variabel moderasi, memperkuat pengaruh negatif Efisiensi Biaya (BOPO) terhadap profitabilitas bank. Dengan demikian, variabel BOPO dan BOPO.NPL secara bersama-sama dapat menjelaskan variasi variabel dependen ROA sebesar koefisien determinasi yaitu 98,7\% yang dapat dilihat pada Tabel 7. 
Tabel 7. Koefisien Determinasi Data 2019

\begin{tabular}{cccc}
\hline Model & $\mathrm{R}$ & $\mathrm{R}$ Square & SEE \\
\hline & 0,994 & 0,987 & 0,003 \\
\hline
\end{tabular}

Sumber: Data Penelitian, 2021

Angka R sebesar 0,994 menunjukkan bahwa korelasi antara variabel independent dengan variabel dependennya kuat, dimana angka $\mathrm{R}$ melebihi 0,5. Sedangkan angka R Square sebesar 0,987 berarti 98,7\% variasi dari ROA dapat dijelaskan oleh variasi dari variabel BOPO dan BOPO.NPL, sedangkan sisanya sebesar $1,3 \%$ dijelaskan oleh sebab-sebab lain. Nilai SEE (standard error of estimate) sebesar 0,003 termasuk rendah, maka model regresi tepat dalam memprediksi variabel dependen. Analisa dilakukan juga untuk data tahun 2020. Statistik deskriptif disajikan untuk memberikan gambaran (deskripsi) mengenai perilaku data, seperti nilai terendah, nilai tertinggi, sebaran, rata-rata, deviasi standar, dan varians data

Tabel 8. Hasil Analisis Statistik Deskriptif Penelitian Data 2020

\begin{tabular}{lccc}
\hline & N & Mean & Std. Deviation \\
\hline ROA & 39 & $-0,001$ & 0,043 \\
LDR & 39 & 0,962 & 0,309 \\
BOPO & 39 & 1,077 & 0,534 \\
CAR & 39 & 0,402 & 0,391 \\
NPL & 39 & 0,039 & 0,037 \\
\hline
\end{tabular}

Sumber: Data Penelitian, 2021

Pada Tabel 8, dapat dilihat jumlah populasi (N) penelitian ini adalah 39. Mean yang dimiliki ROA sebesar -0,00164, artinya rata-rata ROA bank kategori BUKU 1 selama periode triwulan 2 sampai dengan 4 tahun 2020 adalah -0,00164, memburuk jika dibandingkan dengan mean ROA periode yang sama tahun 2020 yaitu 0,00274. Standar deviasi atau penyimpangan nilai terhadap rata-rata ROA adalah 0,043910 membesar dibandingkan dengan tahun 2019. Hal ini menunjukkan fluktuasi perolehan profitabilitas semakin lebar. Untuk menguji apakah nilai residu dari regresi mempunyai distribusi normal, maka dilakukan Uji Normalitas.

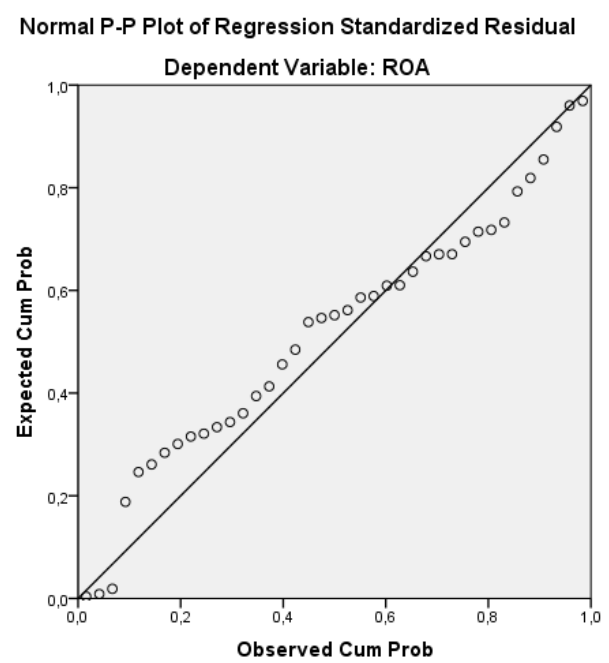

Gambar 6. Hasil Uji Normalitas Data 2020

Sumber: Data Penelitian, 2021 
Pada Gambar 6 dapat dilihat hasil Uji Normalitas yaitu data 2020 berdistribusi normal karena penyebaran datanya di sekitar dan mengikuti arah garis diagonal. Langkah berikutnya adalah Uji Heteroskedastisitas untuk mengetahui ada atau tidaknya kesamaan varians residual antar pengamatan.

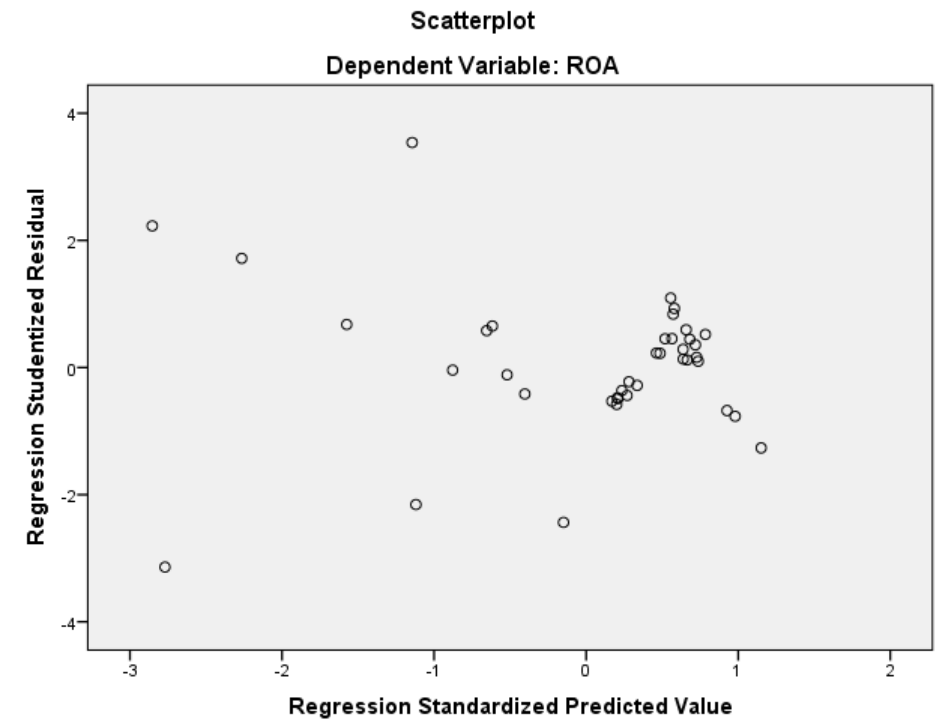

Gambar 7. Hasil Uji Heteroskedastisitas Data 2020

Sumber: Data Penelitian, 2021

Pada Gambar 7, dapat dilihat hasil Uji Heteroskedastisitas berupa scatterplot, yaitu tidak terdapat masalah heteroskedastisitas karena penyebaran titik-titik tidak membentuk pola yang jelas. Untuk menguji apakah pada model regresi ditemukan adanya korelasi antar-variabel independen, maka dilakukan Uji Multikolinieritas.

Tabel 9. Hasil Uji Multikolinieritas Data 2020

\begin{tabular}{lcc}
\hline \multirow{2}{*}{ Model } & \multicolumn{2}{c}{ Collinearity Statistics } \\
\cline { 2 - 3 } & Tolerance & VIF \\
\hline LDR & 0,772 & 1,296 \\
BOPO & 0,570 & 1,754 \\
CAR & 0,486 & 2,059 \\
NPL & 0,730 & 1,369 \\
\hline
\end{tabular}

Sumber: Data Penelitian, 2021

Pada Tabel 9, dapat dilihat hasil Uji Multikolinieritas, dimana variabel CAR tidak mempunyai nilai collinearity tolerance mendekati angka 1 dan tidak mempunyai nilai VIF di sekitar angka 1. Maka, peneliti menggunakan perlakuan sama dengan data 2019, yaitu melakukan uji ulang dengan mengeluarkan variabel CAR dari model regresi. Uji Normalitas dilakukan kembali untuk menguji apakah nilai residu dari regresi yang baru mempunyai distribusi normal.

Pada Gambar 8 dapat dilihat hasil Uji Normalitas bahwa data berdistribusi normal. Selanjutnya, dilakukan kembali Uji Heteroskedastisitas pada model regresi baru. 


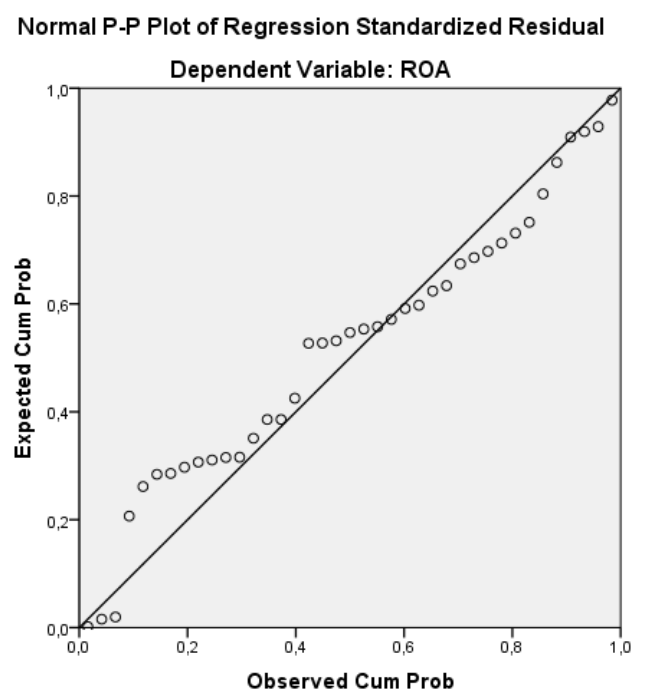

Gambar 8. Hasil Uji Normalitas Data 2020 (2)

Sumber: Data Penelitian, 2021

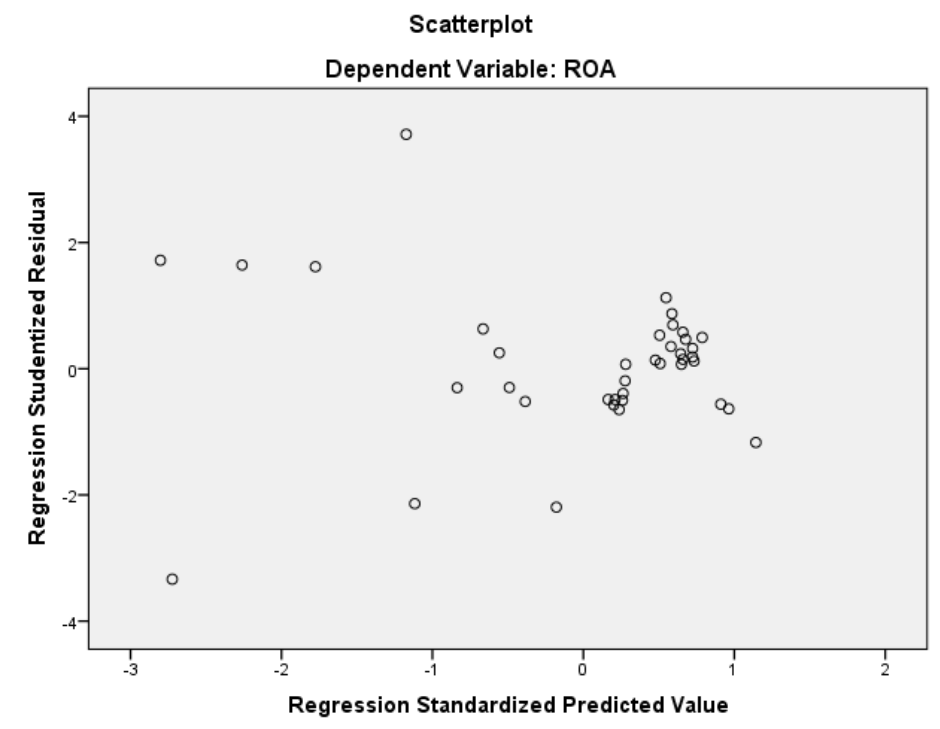

Gambar 9. Hasil Uji Heteroskedastisitas Data 2020 (2)

Sumber: Data Penelitian, 2021

Pada Gambar 9, dapat dilihat hasil Uji Heteroskedastisitas berupa scatterplot, yaitu tidak terdapat masalah heteroskedastisitas karena penyebaran titik-titik tidak membentuk pola yang jelas. Untuk menguji apakah pada model regresi ditemukan adanya korelasi antar variabel independent LDR, BOPO, dan NPL, maka dilakukan Uji Multikolinieritas.

Tabel 10. Hasil Uji Multikolinieritas Data 2020 (2)

\begin{tabular}{lcc}
\hline Model & \multicolumn{2}{c}{ Collinearity Statistics } \\
\cline { 2 - 3 } & Tolerance & VIF \\
\hline LDR & 0,995 & 1,005 \\
BOPO & 0,937 & 1,068 \\
NPL & 0,935 & 1,069 \\
\hline
\end{tabular}

Sumber: Data Penelitian, 2021 
Pada Tabel 10, dapat dilihat hasil Uji Multikolinieritas, dimana ketiga variabel independen memiliki nilai collinearity tolerance mendekati angka 1 dan mempunyai nilai VIF di sekitar angka 1. Artinya tidak terdapat korelasi antar variabel independen. Untuk menguji kesesuaian data maka dilakukan Uji Kesesuaian Model (goodness of fit) - F test yang hasilnya dapat dilihat pada Tabel ANOVA.

Tabel 11. Hasil Uji Kesesuaian Model (F-test) Data 2020

\begin{tabular}{llccccc}
\hline Model & & $\begin{array}{c}\text { Sum of } \\
\text { Squares }\end{array}$ & $d f$ & $\begin{array}{c}\text { Mean } \\
\text { Square }\end{array}$ & $F$ & Sig. \\
\hline \multirow{1}{*}{1} & Regression & 0,071 & 3 & 0,024 & 454,674 & $0,000^{\mathrm{b}}$ \\
& Residual & 0,002 & 35 & 0,000 & & \\
& Total & 0,073 & 38 & & & \\
\hline
\end{tabular}

Sumber: Data Penelitian, 2021

Pada Tabel 11, dapat dilihat bahwa $p$-value sebesar 0,000b yang lebih kecil dari $\alpha=$ 0,05 . Maka dapat disimpulkan bahwa data sesuai. Hasil pengujian model regresi dengan variabel independen LDR, BOPO, dan NPL, dimana NPL merupakan variabel moderasi, sebagai berikut.

Tabel 12. Hasil Analisis Regresi Data 2020

\begin{tabular}{|c|c|c|c|c|c|c|}
\hline \multirow[t]{2}{*}{ Model } & & \multicolumn{2}{|c|}{$\begin{array}{l}\text { Unstandardized } \\
\text { Coefficients }\end{array}$} & \multirow{2}{*}{$\begin{array}{c}\text { Standardized } \\
\text { Coefficients } \\
\text { Beta }\end{array}$} & \multirow[t]{2}{*}{$t$} & \multirow[t]{2}{*}{ Sig. } \\
\hline & & B & Std. Error & & & \\
\hline \multirow[t]{6}{*}{1} & (Constant) & 0,088 & 0,004 & & 22,106 & 0,000 \\
\hline & LDR & $-0,007$ & 0,003 & $-0,051$ & $-2,457$ & 0,019 \\
\hline & $\mathrm{BOPO}$ & $-0,073$ & 0,002 & $-0,889$ & $-38,453$ & 0,000 \\
\hline & NPL & $-0,269$ & 0,101 & $-0,229$ & $-2,653$ & 0,012 \\
\hline & LDR.NPL & 0,485 & 0,069 & 0,566 & 7,020 & 0,000 \\
\hline & BOPO.NPL & $-0,258$ & 0,050 & $-0,384$ & $-5,198$ & 0,000 \\
\hline
\end{tabular}

Sumber: Data Penelitian, 2021

Pada Tabel 12, dapat dilihat bahwa kelima variabel yang digunakan memiliki $p$-value lebih kecil dari $\alpha=0,05$, yang berarti seluruh variabel memiliki pengaruh yang signifikan terhadap profitabilitas. Maka hasil akhir modelnya sebagai berikut.

ROA = 0,088-0,007LDR-0,073BOPO-0,269NPL + 0,485LDR.NPL-0,258BOPO.NPL

Artinya, pada H1 dan H2, yaitu Risiko Likuiditas (LDR) dan Efisiensi Biaya (BOPO) berpengaruh signifikan negatif terhadap profitabilitas bank. Untuk H5 diperoleh Risiko Kredit (NPL) memperkuat pengaruh negatif Risiko Likuiditas (LDR) terhadap profitabilitas bank. Artinya, semakin besar risiko kredit maka semakin besar pengaruh negatif pinjaman yang diberikan bank terhadap profitabilitas bank. Namun, untuk H6, Risiko Kredit (NPL) memperlemah pengaruh negatif Efisiensi Biaya (BOPO) terhadap profitabilitas bank. Kedua hal ini berlawanan dengan hasil penelitian Wicaksana \& Ramantha (2019), dimana rasio NPL memperlemah pengaruh LDR dan memperkuat pengaruh BOPO terhadap profitabilitas. Hasil penelitian ini menunjukkan bahwa Risiko Kredit (NPL) berpengaruh terhadap profitabilitas sebagai variabel independen dan sebagai variabel moderasi (quasi moderator). Dalam kondisi perekonomian yang tidak stabil, Risiko Kredit (NPL) berpengaruh negatif terhadap profitabilitas bank, juga mempengaruhi hubungan antara Risiko Likuiditas (LDR) dan Efisiensi Biaya (BOPO) dengan profitabilitas bank. 
Dengan demikian, variabel LDR, BOPO, NPL, LDR.NPL, dan BOPO.NPL secara bersama-sama dapat menjelaskan variasi variabel dependen ROA sebesar koefisien determinasi yaitu 99,1\% yang dapat dilihat pada Tabel.

Tabel 13. Koefisien Determinasi Data 2020

\begin{tabular}{cccc}
\hline Model & $R$ & $R$ Square & $S E E$ \\
\hline & 0,996 & 0,991 & 0,004 \\
\hline
\end{tabular}

Sumber: Data Penelitian, 2021

Angka $\mathrm{R}$ sebesar 0,996 menunjukkan bahwa korelasi antara variabel independent dengan variabel dependennya kuat, dimana angka $R$ melebihi 0,5. Sedangkan angka R Square sebesar 0,991 berarti 99,1\% variasi dari ROA dapat dijelaskan oleh variasi dari variabel LDR, BOPO, NPL, LDR.NPL, dan BOPO.NPL, sedangkan sisanya sebesar $0,9 \%$ dijelaskan oleh sebab-sebab lain. Nilai SEE (standard error of estimate) sebesar 0,004 termasuk rendah, maka model regresi tepat dalam memprediksi variabel dependen.

\section{SIMPULAN}

Dalam kondisi perekonomian yang normal pada periode triwulan 2 sampai dengan 4 tahun 2019, manajemen bank kategori BUKU 1 perlu memperhatikan efisiensi biaya karena ketika muncul masalah kredit macet, akan sangat menurunkan kinerja profitabilitas bank. Namun, dalam kondisi perekonomian yang tidak stabil pada periode triwulan 2 sampai dengan 4 tahun 2020, manajemen bank kategori BUKU 1, tidak hanya perlu memperhatikan efisiensi biaya dan risiko kredit macet, tetapi juga harus memperhatikan risiko likuiditas untuk menjaga dan meningkatkan profitabilitas bank. Sehubungan dengan pendekatan pengambilan keputusan pada lembaga keuangan menurut Rose \& Hudgins (2013), temuan pada studi ini mendukung pendekatan liability management.

Penelitian terdahulu yang dilakukan oleh Wicaksana \& Ramantha (2019), menyarankan penggunaan variabel bebas lain yang dapat berpengaruh terhadap profitabilitas, salah satunya adalah kecukupan modal. Namun hasil penelitian ini menunjukkan bahwa tingkat kecukupan modal tidak dapat menjelaskan fenomena profitabilitas. Untuk penelitian selanjutnya, peneliti menyarankan untuk menggunakan variabel-variabel bebas lain serta meneliti kategori bank lain.

\section{REFERENSI}

Adelopo, I., Lloydking, R., \& Tauringana, V. (2018). Determinants of bank profitability before, during, and after the financial crisis. International Journal of Managerial Finance, 14(4), 378-398. https:/ / doi.org/10.1108/IJMF-07-20170148

Afriyeni, A., \& Fernos, J. (2018). Analisis Faktor-Faktor Penentu Kinerja Profitabilitas Bank Perkreditan Rakyat (BPR) Konvensional Di Sumatera Barat. Jurnal Benefita, 3(3), 325-335. https:/ / doi.org/10.22216/jbe.v3i3.3623

Ardana, Y. (2018). Faktor Eksternal dan Internal yang Mempengaruhi Profitabilitas Bank Syariah di Indonesia. Cakrawala, 13(1), 51. https://doi.org/10.31603/cakrawala.v13i1.2042

Ercegovac, R., Klinac, I., \& Zdrilić, I. (2020). Bank specific determinants of eu banks profitability after 2007 financial crisis. Management (Croatia), 25(1), 89-102. https://doi.org/10.30924/mjcmi.25.1.5 
Gyulai, L., \& Szucs, G. (2017). The Effect of the Economic Crisis on the Bank Profitability in the V4 Countries. Management, Enterprise and Benchmarking in the 21st Century, 97-110.

Hunjra, A. I., Mehmood, A., Nguyen, H. P., \& Tayachi, T. (2020). Do firm-specific risks affect bank performance? International Journal of Emerging Markets. https://doi.org/10.1108/IJOEM-04-2020-0329

Işık, A. (2009). Factors Influencing the Profitability of EU Banks' Before and During the Financial Crisis. In İstanbul Gelişim Üniversitesi Sosyal Bilimler Dergisi. https://dergipark.org.tr/en/pub/igusbd/article/282534

Jumono, S., Sugiyanto, \& Mala, C. M. (2018). Why Have Bank Profitability Been High in Indonesia? An Analysis Using Dynamic Panel Data Approach. Journal of Economic \& Management Perspectives, 12(2), 353-367.

Knezevic, A., \& Dobromirov, D. (2016). The determinants of Serbian banking industry profitability. Economic Research-Ekonomska Istrazivanja , 29(1), 459474. https:// doi.org/10.1080/1331677X.2016.1174390

Korytowski, M. (2018). Banks' Profitability Determinants in Post-crisis European Union. International Journal of Finance \& Banking Studies, 7(1), 1-12.

Kramaric, T. P., Cipcic, M. L., \& Miletic, M. (2017). Has the Financial Crisis Affected the Profitability of Banks in Croatia? Journal of Applied Finance E Banking, 7(3), 21-45. file:// /C:/Users/cgree/Downloads/out (54).pdf

Nisar, S., Peng, K., Wang, S., \& Ahmed, J. (2017). Banking Sector Profitability, Before, During and After Global Financial Crisis: Evidence from a Developing Economy. International Journal of Finance \& Banking Studies (2147-4486), 6(3), 22. https://doi.org/10.20525/ijfbs.v6i3.722

Nuha, V. Q. Q., \& Mulazid, A. S. (2018). PROFITABILITAS BANK UMUM SYARIAH DI INDONESIA Vista Qonitah Qotrun Nuha, Ade Sofyan Mulazid. Al-Uqud: Journal of Islamic Economics, 2(95), 168-182.

Nurul, H. (2020). Apa Itu Bank BUKU 1? Ini Definisi dan Daftar Nama Banknya. In 2020. https://lifepal.co.id/media/bank-buku-1/

Parenrengi, S., \& Hendratni, T. W. (2018). Pengaruh Dana Pihak Ketiga, Kecukupan Modal dan Penyaluran Kredit Terhadap Profitabilitas Bank. Jurnal Manajemen Strategi Dan Aplikasi Bisnis, 1(1), 9-18. https://doi.org/10.36407/jmsab.v1i1.15

Park, C., \& Shin, K. (2021). COVID-19, nonperforming loans, and cross-border bank lending. Journal of Banking and Finance.

Pinasti, W. F., \& Mustikawati, R. I. (2018). Pengaruh CAR, BOPO, NPL, NIM dan LDR Terhadap Profitabilitas Bank Umum Periode 2011-2015. Nominal: Barometer Riset Akuntansi Dan Manajemen, 7(1), 126-142. https://doi.org/10.21831/nominal.v7i1.19365

Prasanto, O., Wulandari, D., Narmaditya, B. S., \& Kamaludin, M. (2020). Determinants of Bank Profitability: a New Evidence From State-Owned Banks in Indonesia. Trikonomika, 19(1), 29-35. https://doi.org/10.23969/trikonomika.v19i1.1443

Republika. (2021). Akibat Pandemi, Laba Bank Susut Hingga 40 Persen. In Republika.Co.Id. https://www.republika.co.id/berita/qnw1n2457/akibatpandemi-laba-bank-susut-hingga-40-persen

Rose, P. S., \& Hudgins, S. C. (2013). Bank Management E Financial Services (9th ed.). 
McGraw-Hill.

Saif-Alyousfi, A. Y. H. (2020). Determinants of bank profitability: evidence from 47 Asian countries. Journal of Economic Studies. https:// doi.org/10.1108/JES-052020-0215

Saleh, I., \& Abu Afifa, M. (2020). The effect of credit risk, liquidity risk and bank capital on bank profitability: Evidence from an emerging market. Cogent Economics and Finance, 8(1), 1-14. https://doi.org/10.1080/23322039.2020.1814509

Salike, N., \& Ao, B. (2018). Determinants of bank's profitability: role of poor asset quality in Asia. China Finance Review International, 8(2), 216-231. https:/ /doi.org/10.1108/CFRI-10-2016-0118

Shahid1, M. S., Gul, F., \& Naheed, K. (2019). Credit Risk and Financial Performance of Banks : Evidence from Pakistan. NUML International Journal of Business $\mathcal{E}$ Management, 14(1), 144-155.

Sofie, M., Manurung, A. H., Usman, B., \& Trisakti, U. (2020). Determinants of Bank Profitability with Size as Moderating Variable. Journal of Applied Finance $\mathcal{E}$ Banking, 10(March), 1792-6599. https://www.researchgate.net/publication/339434242

Sofyan, M. (2019). Faktor-Faktor Yang Mempengaruhi Profitabilitas Bank Perkreditan Rakyat (BPR) di Provinsi Jawa Timur. Jurnal Inspirasi Bisnis Dan Manajemen, 3(1), 63-76. https://doi.org/10.33603/jibm.v3i1.2093

Sudarsono, H. (2017). Analisis Pengaruh Kinerja Keuangan terhadap Profitabilitas Bank Syariah di Indonesia. Economica: Jurnal Ekonomi Islam, 8(2), 175-203.

Sugiarto, S., \& Lestari, H. S. (2017). Faktor-Faktor yang Mempengaruhi Profitabilitas Bank pada Bank Konvensional yang Terdaftar di Bursa Efek Indonesia. Jurnal Manajemen Dan Pemasaran Jasa, 10(2), 267-280. https://doi.org/10.25105/jmpj.v10i2.2510

Topak, M. S., \& Talu, N. H. (2017). Bank Specific nad Macroeconomic Determinants of Bank Profitability: Evidence from Turkey. International Journal of Economics and Financial Issues, 7(2), 574-584.

Wicaksana, I. G. H. D., \& Ramantha, I. W. (2019). Pengaruh Pinjaman yang Diberikan dan BOPO Pada Profitabilitas dengan Risiko Kredit sebagai Pemoderasi. E-Jurnal Akuntansi Universitas Udayana, 27(2), 1013-1037.

Winarto, Y. (2020). Peran perbankan sangat besar dalam menggerakkan ekonomi nasional. In Kontan.co.id. https://keuangan.kontan.co.id/news/peranperbankan-sangat-besar-dalam-menggerakkan-ekonomi-nasional 